\title{
KEPATUHAN PENGGUNAAN ALAT PELINDUNG DIRI (APD) MASKER DITINJAU DARI PENGETAHUAN DAN SIKAP PEKERJA
}

\section{COMPLIANCE USE PERSONAL PROTECTIVE EQUIPMENT (PPE) OF MASKS ASSESSED FROM WORKERS KNOWLEDGE AND ATTITUDES}

\author{
Agus Aan Adriansyah ${ }^{1 *}$, Suyitno', Nikmatus Sa'adah ${ }^{2}$ \\ ${ }^{1}$ Program Studi S1 Kesehatan Masyarakat, Fakultas Kesehatan, Universitas Nahdlatul Ulama \\ Surabaya, Jl. Raya Jemursari 51-57 60237, Surabaya, Jawa Timur, Indonesia \\ ${ }^{2}$ Program Studi Pendidikan Dokter Gigi, Institut Ilmu Kesehatan Bhakti Wiyata, Kediri, \\ Jl. KH. Wahid Hasyim 65, 64114, Kediri, Jawa Timur, Indonesia \\ *email: aan.naufal87@unusa.ac.id
}

\begin{abstract}
Sandstone mining in the Gunung Maddah area of Sampang Regency is an informal industry with a great risk of accumulating dust in the respiratory tract and causing Acute Respiratory Infections (ISPA). Besides the company does not provide PPE masks, this problem is due to the lack of knowledge and attitudes of workers regarding the use of PPE masks in mining. This study aims to analyze the relationship between knowledge and attitudes with compliance with the use of PPE masks on sandstone mining workers of PT. Sirtu Emas Sampang Regency. This type of research used an analytic survey design with a cross-sectional approach. The sample used was 56 mining workers with the purposive sampling technique. The results of this study indicate $p$-value $=0.004$ for the relationship between knowledge and compliance with the use of PPE on masks and p-value $=0.034$ for the relationship between attitude and compliance with the use of PPE on masks. The conclusion obtained is that there is a significant relationship between knowledge and attitudes with compliance with the use of PPE masks. The better the knowledge and attitudes the workers have; the more obedient workers will be in using PPE masks. Suggestions that can be given are the need to monitor the use of PPE in the work environment and provide massive information to workers.
\end{abstract}

Keywords: Knowledge, Attitude, Compliance, PPE Mask

\begin{abstract}
Abstrak
Pertambangan batu pasir di Daerah Gunung Maddah Kabupaten Sampang, merupakan industri informal dengan risiko yang besar untuk mengalami penimbunan debu pada saluran pernapasan dan menyebabkan penyakit Infeksi Saluran Pernapasan Akut (ISPA). Disamping perusahaan tidak menyediakan APD masker, permasalahan tersebut disebabkan kurangnya pengetahuan dan sikap pekerja terkait penggunaan APD masker di pertambangan. Penelitian ini bertujuan menganalisis hubungan pengetahuan dan sikap dengan kepatuhan penggunaan APD masker pada pekerja tambang batu pasir PT. Sirtu Emas Kabupaten Sampang. Jenis penelitian ini menggunakan desain survei analitik dengan pendekatan cross sectional. Sampel yang digunakan sebesar 56 pekerja tambang dengan tekhnik purposive sampling. Hasil penelitian ini menunjukkan $\mathrm{p}$ value $=0,004$ untuk hubungan pengetahuan dengan kepatuhan penggunaan APD Masker dan $\mathrm{p}$ value $=0,034$ untuk hubungan sikap dengan kepatuhan penggunaan APD Masker. Kesimpulan yang diperoleh yaitu terdapat hubungan yang signifikan antara pengetahuan dan sikap dengan kepatuhan penggunaan APD masker. Semakin baik pengetahuan dan sikap yang dimiliki pekerja, maka pekerja semakin patuh dalam penggunaan APD Masker. Saran yang dapat diberikan adalah perlunya pengawasan penggunaan APD di lingkungan kerja dan pemberian informasi secara masif pada para pekerja.
\end{abstract}

Kata kunci: Pengetahuan, Sikap, Kepatuhan, APD Masker 


\section{PENDAHULUAN}

Industri pertambangan batu pasir merupakan salah satu industri yang memiliki potensi bahaya paparan debu terhirup oleh pekerja. Kadar pencemaran udara dapat mengganggu kesehatan pekerja tambang. Apabila terus berlanjut, dapat menyebabkan gangguan pernapasan dengan munculnya gejala batuk dan sesak napas (Achmadi, 2014).

Pertambangan batu pasir di Daerah Gunung Maddah Kabupaten Sampang, merupakan industri informal dengan memiliki risiko yang cukup besar yaitu banyak debu yang akan terhirup dan dapat mengganggu saluran pernapasan para pekerja. Debu yang bertebaran dihasilkan dari proses produksi yaitu pemecahan gunung, pengangkutan, penggilingan, pencampuran dan penimbangan. Jika aktivitas bernapas yang sering disertai hirupan debu, dapat menyebabkan terjadinya penyakit Infeksi Saluran Pernapasan Akut (ISPA).

ISPA lebih banyak terjadi di Negara berkembang dari pada di Negara maju. ISPA terdapat diseluruh dunia dengan jumlah 18,8 miliar dan terjadi kematian sebanyak 4 juta orang pertahunnya (WHO, 2012). ISPA di Indonesia tahun 2015 menempati urutan pertama sebanyak 25.000 jiwa se-Asia Tenggara. Jawa Timur masuk ke dalam 5 Provinsi di Indonesia dengan ISPA tertinggi yaitu mencapai $28,3 \%$ (Kemenkes RI., 2013).

Berdasarkan data laporan Puskesmas Banyuanyar pada bulan Agustus sampai Oktober 2019, terdapat 636 orang menderita ISPA. Dari keseluruhan pasien penderita ISPA yang berobat di Puskesmas tersebut, didalamnya termasuk pula para pekerja tambang, meskipun jumlahnya tidak banyak dan tidak ada detail data yang bisa diberikan pihak Puskesmas. Akan tetapi, hasil observasi yang telah dilakukan di penambang batu pasir menunjukkan terdapat hampir sebagian besar pekerja $(42,86 \%)$ yang pernah mengalami riwayat ISPA dengan gejala susah untuk bernapas serta telah melakukan pemeriksaan kesehatan di Puskesmas. Berdasarkan studi pendahuluan, sebagian besar pekerja memiliki pengetahuan dan sikap kurang baik tentang penggunaan APD dengan persentase masing-masing sebesar 57,14\%.

Berdasarkan latar belakang tersebut, maka tujuan dari penulisan artikel ini adalah menganalisis hubungan pengetahuan dan sikap para pekerja dengan kepatuhan penggunaan APD masker pada pekerja tambang batu pasir PT. Sirtu Emas Kabupaten Sampang.

\section{METODE PENELITIAN}

Penelitian ini dilakukan di tambang batu pasir PT. Sirtu Emas Kabupaten Sampang pada bulan Juni 2020. Jenis penelitian ini adalah kuantitatif menggunakan desain observasional analitik dengan pendekatan cross sectional. Variabel yang diteliti yaitu pengetahuan, sikap dan kepatuhan penggunaan APD masker dari para pekerja. Variabel pengetahuan dan sikap merujuk pada teori Green (1980). Variabel pengetahuan diukur melalui pentingnya penggunaan APD, bahaya jika tidak memakai APD dan jenis-jenis APD masker. Variabel sikap diukur melalui reaksi atau respon pekerja terkait pemakaian APD saat bekerja.

Variabel kepatuhan merujuk pada teori kepatuhan menurut Blass dengan aspek yang diukur meliputi mempercayai (belief), menerima (accept) dan melakukan (act) (Blass, 1999). Hasil pengukuran kepatuhan kemudian dikategorikan menjadi "patuh" dan "tidak patuh". Setiap variabel yang diukur akan menghasilkan data berskala ordinal. Populasi penelitian ini adalah seluruh pekerja tambang batu pasir, sedangkan sampel yang diteliti sebesar 56 pekerja tambang yang diambil dengan teknik probability sampling secara Simple Random Sampling. Sumber data primer diperoleh dari hasil penyebaran kuesioner untuk variabel mengukur pengetahuan, sikap, dan kepatuhan. Sedangkan data sekunder diperoleh dari Puskesmas Banyuanyar Kab. Sampang berupa data kejadian ISPA dari bulan Agustus sampai Oktober 2019.

Kuesioner untuk pengambilan data, terlebih dahulu dilakukan pengujian validitas dan reliabilitas. Uji validitas dilakukan dengan mengamati perbandingan nilai $\mathrm{r}$ hitung setiap item pertanyaan dengan nilai $r$ table $(>0,361)$. Hasil yang diperoleh menunjukkan seluruh item pertanyaan dari setiap variabel Pengetahuan, Sikap dan Kepatuhan adalah valid, karena nilai $\mathrm{r}$ hitung (Corrected Item Total Correlation) > $\mathrm{r}$ tabel sebesar 0,361. Uji reliabilitas dilakukan dengan mengamati nilai Alpha Cronbach's (> 0,6). Hasil yang diperoleh menunjukkan tiga variabel adalah reliabel, karena nilai Alpha Cronbach's lebih besar dari 0,60 (Sugiyono, 2012).

Data yang diperoleh selanjutnya dianalisis menggunakan uji statistik korelasi spearman untuk menguji hipotesis hubungan pengetahuan dan sikap dengan kepatuhan penggunaan APD Masker. Di samping itu, hasil analisis dilengkapi pula dengan Prevalensi Ratio (PR) sesuai 
dengan karakteristik masing-masing variabel yang diteliti.

\section{HASIL DAN PEMBAHASAN}

\section{Gambaran Umum Responden}

Berikut ini merupakan rangkaian informasi terkait para pekerja tambang batu pasir PT. Sirtu Emas Kabupaten Sampang, yang menjadi responden dalam penelitian ini.

Berdasarkan Tabel 1 dapat diperoleh informasi bahwa distribusi hampir setengah pekerja memiliki rentang umur 36-45 tahun $(48,2 \%)$. Mayoritas pekerja hanya berlatar belakang pendidikan dasar $(80,3 \%)$. Setengah dari pekerja memiliki lama kerja 3-4 tahun $(50.0 \%)$.

Selanjutnya dapat diinformasikan bahwa, hampir setengah pekerja tambang yang menjadi responden $(37,5 \%)$, memiliki pengetahuan baik dalam menggunakan APD masker di tempat kerja. Akan tetapi, pekerja yang memiliki pengetahuan kurang dalam menggunakan APD masker juga tinggi yaitu hampir setengah dari pekerja $(33,9 \%)$. Pengetahuan pekerja dalam penggunaan APD masker diperoleh melalui sejumlah pernyataan yang diajukan kepada pekerja tambang terkait hal yang wajib diketahui meliputi pentingnya menggunakan APD masker, jenis-jenis APD masker, ketentuan pemakaian masker yang benar, bahaya tidak menggunakan APD masker, dan dampak tidak menggunakan masker sesuai ketentuan yang berlaku. Responden diharapkan mengetahui dan memahami dengan baik seputar penggunaan APD masker. Responden dengan pengetahuan kurang diidentifikasi dari hasil penilaian yang menunjukkan ketepatan jawaban kurang dari $56 \%$ dari total seluruh pertanyaan (Arikunto, 2013). Hasil ini sejalan dengan penelitian Maharani \& Wahyuningsih (2017), yang meneliti terkait pengetahuan, sikap kebijakan K3 dengan penggunaan APD di bagian ring spinning unit 1. Kesimpulan yang didapatkan adalah hampir setengah responden memiliki pengetahuan baik tentang APD. Disamping itu, Sulasmi \& Ibrahim (2018) juga menyatakan bahwa faktor-faktor yang memengaruhi penggunaan APD pada para pekerja penyapu jalan di sepanjang jalan veteran kota Makassar salah satunya adalah pengetahuan. Disebutkan bahwa hampir seluruh pekerja yang menggunakan masker saat bekerja $(92,8 \%)$, memiliki pengetahuan yang baik tentang pemakaian APD.

Tabel 1. Gambaran Umum Karakteristik Responden Penelitian

\begin{tabular}{|c|c|c|c|c|c|}
\hline \multirow{2}{*}{$\frac{\text { No. }}{1}$} & \multicolumn{2}{|l|}{ Informasi } & Kategori & \multirow{2}{*}{$\begin{array}{r}\text { Frekuensi }(\mathbf{n = 5 6}) \\
21\end{array}$} & \multirow{2}{*}{$\begin{array}{r}\text { Persentase (\%) } \\
37,5\end{array}$} \\
\hline & Umur & & 1. 26-35 Tahun & & \\
\hline & & & 2. 36-45 Tahun & 27 & 48,2 \\
\hline & & & 3. 46-55 Tahun & 7 & 12,5 \\
\hline & & & 4. 56-65 Tahun & 1 & 1,8 \\
\hline \multirow[t]{3}{*}{2} & Pendidikan & & 1. SD & 45 & 80,3 \\
\hline & & & 2. SMP & 7 & 12,5 \\
\hline & & & 3. SMA & 4 & 7,1 \\
\hline \multirow[t]{4}{*}{3} & Lama Kerja & & 1. 1-2 Tahun & 9 & 16,1 \\
\hline & & & 2. 3-4 Tahun & 28 & 50,0 \\
\hline & & & 3. 5-6 Tahun & 17 & 30,4 \\
\hline & & & 4. 7-8 Tahun & 2 & 3,6 \\
\hline \multirow[t]{3}{*}{4} & Pengetahuan & Penggunaan & 1. Kurang & 19 & 33,9 \\
\hline & APD Masker & & 2. Cukup & 16 & 28,6 \\
\hline & & & 3. Baik & 21 & 37,5 \\
\hline \multirow[t]{2}{*}{5} & Sikap dalam & Penggunaan & 1. Tidak baik & 35 & 44,6 \\
\hline & APD Masker & & 2. Baik & 31 & 55,4 \\
\hline \multirow[t]{2}{*}{6} & Kepatuhan & Penggunaan & 1. Tidak Patuh & 27 & 48,2 \\
\hline & APD Masker & & 2. Patuh & 29 & 51,8 \\
\hline
\end{tabular}

Selain pengetahuan responden, dapat digambarkan pula bahwa setengah dari pekerja memiliki sikap baik dalam menggunakan APD masker $(55,4 \%)$, akan tetapi untuk sikap tidak baik yang dimiliki pekerja dalam menggunakan
APD masker juga tinggi yaitu hampir setengah dari pekerja $(44,6 \%)$. Sikap tidak baik yang dimiliki pekerja ditunjukkan dengan reaksi atau respon berupa penolakan peraturan penggunaan APD masker di tempat kerja. Penolakan terjadi 
karena ketidaknyamanan pekerja didalam pemakaian APD saat bekerja. Hasil ini sejalan dengan penelitian Sulasmi \& Ibrahim tahun 2018 yang berjudul faktor-faktor yang memengaruhi penggunaan APD pada penyapu jalan di sepanjang jalan veteran kota Makassar dengan hasil hampir seluruh responden $(92,8 \%)$ memiliki sikap baik dalam pemakaian APD (Sulasmi \& Ibrahim, 2018). Azwar dalam kajiannya juga menyatakan bahwa terbentuknya sikap seseorang dipengaruhi oleh beberapa hal, antara lain pengalaman pribadi, pengaruh orang lain, kebudayaan, media massa dan faktor emosional (Azwar, 2013). Oleh sebab itu, perlunya dibangun budaya yang baik, adanya aturan yang tegas untuk keselamatan para pekerja, para pekerja yang memiliki sikap positif dapat memengaruhi para pekerja lain untuk bersikap positif pula dalam menyikapi penggunaan APD masker.

Berdasarkan Tabel 1 didapatkan informasi pula bahwa sebagian besar pekerja patuh dalam menggunakan APD masker di tempat kerja $(51,8 \%)$, sedangkan hampir setengah pekerja lainnya tidak patuh dalam menggunakan APD masker di tempat kerja $(48,2 \%)$. Ketidakpatuhan pekerja dalam menggunakan APD masker terkait dengan tidak adanya peraturan maupun sanksi yang jelas untuk diberlakukan di tempat kerja PT. Sirtu Emas. Di samping itu, pihak perusahaan juga tidak menyediakan APD masker kepada para pekerja. Para pekerja dengan inisiatif sendiri membawa masker dari rumah berupa masker medis atau masker bedah (surgical mask).
Kepatuhan dalam penelitian ini diperoleh melalui pernyataan pekerja mengenai perilaku patuh atau tidak dalam penggunaan APD masker di tempat kerja. Selama bekerja, para pekerja yang memiliki masker hampir selalu menggunakannya selama bekerja, meskipun masih ada beberapa yang seringkali diturunkan ke dagu atau dilepas sejenak karena untuk bernapas lebih dalam. Sehingga dalam kondisi masih bekerja, pemakaian masker yang terkadang diturunkan ke dagu atau dilepas sejenak termasuk dalam golongan belum patuh dalam pemakaian APD masker yang benar.

Hasil ini sejalan dengan penelitian Warmuni \& Rusminingsih di tahun 2017, yang berjudul hubungan tingkat pengetahuan dengan kepatuhan pemakaian APD petugas cleaning service di rumah sakit umum bangle. Hasil yang didapatkan bahwa hampir seluruh petugas patuh dalam pemakaian APD (Warmuni \& Rusminingsih, 2020). Disamping itu, dalam penelitian lain yang berjudul pengetahuan, sikap, kebijakan K3 dengan penggunaan APD di bagian ring spinning unit 1 , didapatkan hasil hampir seluruh responden $(80,8 \%)$ patuh dalam menggunakan APD (Maharani \& Wahyuningsih, 2017).

\section{Hubungan Pengetahuan dengan Kepatuhan Penggunaan APD Masker}

Berikut ini merupakan hasil analisis dari hubungan tingkat pengetahuan pekerja dengan kepatuhan di dalam penggunaan APD masker pada tempat kerja tambang batu pasir PT. Sirtu Emas Kabupaten Sampang.

Tabel 2. Hubungan Pengetahuan dengan Kepatuhan Penggunaan APD Masker

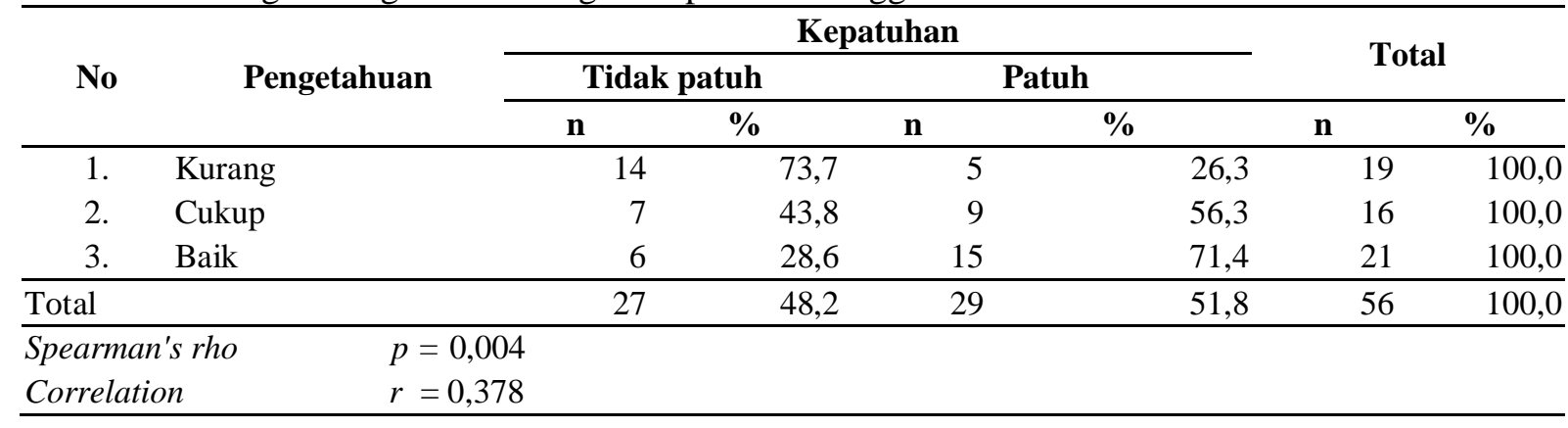

Berdasarkan Tabel 2 didapatkan hasil bahwa sebagian besar pekerja memiliki pengetahuan baik dan patuh dalam menggunakan APD masker di tempat kerja $(71,4 \%)$, sedangkan sebagian besar pekerja lainnya yang memiliki pengetahuan kurang dan tidak patuh dalam menggunakan APD masker di tempat kerja $(73,7 \%)$. Pekerja yang memiliki pengetahuan kurang baik, akan tetapi patuh dalam menggunakan APD sebesar 26,3\%. Pekerja yang memiliki pengetahuan cukup baik, akan tetapi patuh dalam menggunakan APD sebesar 56,3\%. Sementara itu, pekerja yang memiliki pengetahuan baik dan patuh dalam menggunakan APD sebesar 71,4\%. Hasil penilaian persentase tersebut menunjukkan 
bahwa apabila pengetahuan yang dimiliki pekerja terkait penggunaan APD semakin baik, maka para pekerja juga akan lebih patuh dalam menggunakan APD masker di tempat kerja.

Hasil uji statistik dari Spearman's rho diperoleh nilai $p$ value sebesar $0,004<$ alpha $(0,05)$. Angka ini menunjukkan bahwa $\mathrm{H}_{0}$ ditolak dengan kesimpulan adanya hubungan secara signifikan antara pengetahuan dengan kepatuhan penggunaan APD masker pada pekerja tambang batu pasir. Sementara itu, kekuatan hubungan yang dimiliki antara pengetahuan dengan kepatuhan penggunaan APD dapat dilihat dari nilai Correlations sebesar 0,378 , yang artinya cukup kuat. Oleh sebab itu, kesimpulan akhir yang dapat diputuskan adalah terdapat hubungan yang cukup kuat dan bermakna antara pengetahuan yang dimiliki pekerja dengan kepatuhan para pekerja didalam penggunaan APD masker saat bekerja.

Penelitian ini sejalan dengan penelitian sebelumnya mengenai hubungan tingkat pengetahuan dengan kepatuhan pemakaian APD petugas cleaning service di rumah sakit umum bangle, yang menunjukkan hasil terdapat hubungan yang signifikan antara pengetahuan dengan kepatuhan pemakaian APD (Warmuni \& Rusminingsih, 2020). Disamping itu, penelitian lain yang berjudul hubungan pengetahuan, pendidikan dan pelatihan dengan kepatuhan penggunaan APD pada petugas penyapu jalan kecamatan Bangkinan Kota, menunjukkan hasil bahwa adanya hubungan yang signifikan antara pengetahuan dengan kepatuhan penggunaan APD (Lestari \& Pratama, 2019).

Azzahri \& Ikhwan, dalam penelitiannya tahun 2019, juga menyatakan bahwa terdapat hubungan tingkat pengetahuan dengan penggunaan alat pelindung diri pada perawat di Puskesmas Kuok (Azzahri \& Ikhwan, 2019). Penelitiannya lain juga banyak yang menunjukkan bahwa tingkat pengetahuan pekerja tentang penggunaan alat pelindung diri (APD) berhubungan sangat erat dengan penggunaan alat pelindung diri dalam melaksanakan pekerjaannya (Apriluana, 2016; Damanik, 2018; Astuti, 2018; Winarti, 2018; Iriani, 2019; Chotimah, 2019; Maramis, Doda, \& Ratag, 2019; Wapah \& Wijaya, 2020).

\section{Hubungan Sikap dengan Kepatuhan Penggunaan APD Masker}

Berikut ini merupakan hasil analisis dari hubungan sikap pekerja dengan kepatuhan di penggunaan APD masker pada tempat kerja PT. Sirtu Emas Kabupaten Sampang.

Tabel 3. Hubungan Sikap dengan Kepatuhan Penggunaan APD Masker

\begin{tabular}{|c|c|c|c|c|c|c|c|}
\hline \multirow{3}{*}{ No. } & \multirow{3}{*}{ Sikap } & \multicolumn{4}{|c|}{ Kepatuhan } & \multirow{2}{*}{\multicolumn{2}{|c|}{ Total }} \\
\hline & & \multicolumn{2}{|c|}{ Tidak patuh } & \multicolumn{2}{|c|}{ Patuh } & & \\
\hline & & $\mathrm{n}$ & $\%$ & $\mathbf{n}$ & $\%$ & $\mathbf{n}$ & $\%$ \\
\hline 1. & Tidak Baik & 16 & 64,0 & 9 & 36,0 & 25 & 100,0 \\
\hline 2. & Baik & 11 & 35,5 & 20 & 64,5 & 31 & 100,0 \\
\hline Total & & 27 & 39,3 & 29 & 60,7 & 56 & 100,0 \\
\hline Spearmer & rho & & & & & & \\
\hline Correlati & & & & & & & \\
\hline
\end{tabular}

Berdasarkan Tabel 3 didapatkan hasil yaitu sebagian besar pekerja $(64,5 \%)$ memiliki sikap baik dan patuh dalam menggunakan APD masker. Disamping itu, sebagian besar pekerja lainnya $(64,0 \%)$ memiliki sikap tidak baik dan tidak patuh menggunakan APD masker. Pekerja yang memiliki sikap tidak baik terkait pemakaian APD masker, akan tetapi tetap patuh dalam menggunakan APD sebesar 36,0\%. Sementara itu, pekerja yang memiliki sikap baik terkait pemakaian APD masker dan patuh dalam menggunakan APD sebesar 64,5\%. Hasil penilaian persentase tersebut menunjukkan bahwa apabila sikap yang dimiliki pekerja terkait pemakaian APD semakin baik, maka para pekerja juga akan lebih patuh dalam menggunakan APD masker di tempat kerja.

Hasil uji statistik Spearman's rho diperoleh nilai $p$ value sebesar $0,034<$ alpha $(0,05)$. Angka ini menunjukkan bahwa $\mathrm{H}_{0}$ ditolak dengan simpulan adanya hubungan yang signifikan antara sikap pekerja terkait penggunaan APD masker dengan kepatuhan pekerja dalam penggunaan APD masker di tempat kerja tambang batu pasir. Sementara itu, kekuatan hubungan yang dimiliki antara sikap dan kepatuhan dapat dilihat dari nilai Correlations sebesar 0,284 yang artinya terdapat hubungan yang cukup kuat antara sikap para pekerja dengan kepatuhan penggunaan APD masker. 
Berdasarkan hasil Prevalensi Ratio (PR) diperoleh nilai sebesar 3, sehingga dapat diartikan pekerja yang memiliki sikap yang tidak baik terkait penggunaan APD masker, akan berpeluang 3 kali lebih besar untuk tidak patuh dalam penggunaan APD masker di tempat kerja daripada pekerja tambang yang memiliki sikap baik.

Penelitian ini sejalan dengan penelitian sebelumnya mengenai hubungan pengetahuan, sikap, ketersediaan APD dengan kepatuhan pemakaian APD pekerja bagian weaving PT. Iskandar Indah Printing Textile dengan hasil adanya hubungan yang signifikan antara sikap dengan kepatuhan pemakaian APD (Soendoro, 2016). Disamping itu, penelitian lain yang berjudul pengetahuan, sikap, kebijakan K3 dengan penggunaan APD di bagian ring spinning unit 1 , menunjukkan hasil bahwa terdapat hubungan antara sikap dengan kepatuhan menggunakan APD (Maharani \& Wahyuningsih, 2017).

Penelitiannya lain juga banyak yang menunjukkan bahwa sikap pekerja dalam penggunaan alat pelindung diri (APD) berhubungan sangat erat dengan penggunaan alat pelindung diri dalam melaksanakan pekerjaannya (Apriluana, 2016; Ayed \& Yusuf, 2017; Winarti, 2018; Astuti, 2018).

\section{KESIMPULAN DAN SARAN}

\section{Kesimpulan}

Berdasarkan hasil penelitian mengenai hubungan pengetahuan dan sikap dengan kepatuhan penggunaan APD masker, dapat disimpulkan bahwa hanya terdapat hampir setengah pekerja tambang yang memiliki pengetahuan baik terkait penggunaan APD masker, hanya sebagian besar pekerja tambang juga yang memiliki sikap baik terkait penggunaan APD masker, dan sebagian besar pekerja tambang memiliki kepatuhan yang tidak terlalu baik dalam penggunaan APD masker ditempat kerja. Hasil analisis menunjukkan bahwa pengetahuan dan sikap memiliki hubungan yang signifikan dan cukup kuat dengan kepatuhan para pekerja didalam penggunaan APD masker pada tambang batu pasir. Semakin baik tingkat pengetahuan dan sikap yang dimiliki pekerja, maka semakin patuh pula para pekerja dalam menggunakan APD masker di tempat kerja.
Berdasarkan penelitian yang telah dilakukan, maka saran yang dapat diberikan oleh yaitu adanya upaya penegakan peraturan dan pemberian sanksi bagi pekerja yang tidak taat dalam penggunaan APD saat bekerja. Selain itu, perlunya penyuluhan secara rutin tentang penggunaan APD masker yang ditujukan kepada seluruh pekerja tambang batu pasir, demi menjaga kondisi para pekerja agar tidak rentan untuk terkena penyakit pernapasan.

\section{DAFTAR RUJUKAN}

1] Achmadi. (2014). Kesehatan Masyarakat. Jakarta: Rajawali Pers.

2] Apriluana, G. (2016). Hubungan antara Usia, Jenis Kelamin, Lama Kerja, Pengetahuan, Sikap dan Ketersediaan Alat Pelindung Diri (APD) dengan Perilaku Penggunaan APD pada Tenaga Kesehatan. Jurnal Publikasi Kesehatan Masyarakat Indonesia, $\quad 3(3), \quad$ 82-87. doi:http://dx.doi.org/10.20527/jpkmi.v3i3. 2754

3] Arikunto, S. (2013). Prosedur Penelitian. Jakarta: Rineka Cipta.

4] Astuti, Y. (2018). Hubungan Tingkat Pengetahuan dan Sikap Perawat dengan Tingkat Kepatuhan Penggunaan APD di Ruang ICU, IGD dan Irna Imam Bonjol RSUD Kanjuruhan Kepanjen Kabupaten Malang. Nursing News : Jurnal Ilmiah Keperawatan, 3(3), 663-669. Retrieved from

https://publikasi.unitri.ac.id/index.php/fike s/article/view/1375

5] Ayed, S. M., \& Yusuf, M. (2017). Kesadaran Perawat dalam Penggunaan Alat Pelindung Diri (APD). Jurnal Ilmiah Mahasiswa Fakultas Keperawatan, 2(3), 18. Retrieved from http://jim.unsyiah.ac.id/FKep/article/view/ 4324

6] Azwar, S. (2013). Sikap Manusia Teori dan Pengukurannya (2 ed.). Yogyakarta: Pustaka Belajar.

7] Azzahri, L. M., \& Ikhwan, K. (2019). Hubungan Pengetahuan Tentang Penggunaan Alat Pelindung Diri (APD) Dengan Kepatuhan Penggunaan APD Pada Perawat di Puskesmas Kuok. PREPOTIF: Jurnal Kesehatan Masyarakat, 3(1), 50-57. 
doi:https://doi.org/10.31004/prepotif.v3i1. 442

8] Blass, T. (1999). The Milgram Paradigm After 35 Years: Some Things We Now Know About Obedience to Authority. Journal of Applied Social Psychology, 29(5), 955-978. doi:https://psycnet.apa.org/doi/10.1111/j.1 559-1816.1999.tb00134.x

9] Chotimah, C. C. (2019). Pengaruh Pengetahuan, Motivasi dan Persepsi Risiko tentang Penggunaan Alat Pelindung Diri Dasar terhadap Perilaku Penggunaan Alat Pelindung Diri Dasar yang Dimoderasi Faktor Pengawasan pada Civitas Hospitalia RSGMP Unsoed. Jurnal Ekonomi, Bisnis, dan Akuntansi (JEBA), 21(3), 1-11. doi:https://doi.org/10.32424/jeba.v21i3.13 67

10] Damanik. (2018). Konsep Dasar Keperwatan. Jakarta: Bumi Medika.

11] Iriani, R. (2019). Relationship of Education, Knowledge and Work Period with Nurse Compliance Level in the Use of PPE in Harum Sisma Medika Hospital in 2019. Jurnal Persada Husada Indonesia, 6(22), 21-27. Retrieved from http://jurnal.stikesphi.ac.id/index.php/Kese hatan/article/view/223

12] Kemenkes RI. (2013). Riset Kesehatan Dasar. Jakarta: Badan Penelitian dan Pengembangan Kesehatan Kementerian Kesehatan RI.

13] Lestari, R. R., \& Pratama, A. P. (2019). Hubungan Pengetahuan, Pendidikan dan Pelatihan dengan Tingkat Kepatuhan Penggunaan APD pada Petugas Penyapu Jalan di Kecamatan Bangkinang Kota. PREPOTIF: Jurnal Kesehatan Masyarakat, $\quad 3(1), \quad$ 1-10. doi:https://doi.org/10.31004/prepotif.v3i1. 387

14] Maharani, D. P., \& Wahyuningsih, A. S. (2017). Pengetahuan Sikap Kebijakan K3 dengan Penggunaan Alat Pelindung Diri di Bagian Ring Spinning Unit 1. Jurnal of Health Education, 2(1), 33-38. doi:https://doi.org/10.15294/jhe.v2i1.1882 3

15] Maramis, D. M., Doda, D. V., \& Ratag, B. T. (2019). Hubungan antara Pengawasan Atasan dan Pengetahuan dengan Tindakan
Penggunaan Alat Pelindung Diri (APD) pada Perawat di Rumah Sakit Umum Daerah (RSUD) Maria Walanda Maramis Kabupaten Minahasa Utara. Jurnal KESMAS, 8(5), 42-50. Retrieved from https://ejournal.unsrat.ac.id/index.php/kes mas/article/view/24953

16] Soendoro, A. (2016). Hubungan Pengetahuan Sikap Ketersediaan APD dengan Kepatuhan Pemakaian APD Pekerja Bagian Weaving PT. Iskandar Indah Printing Textile. Surakarta: Universitas Sebelas Maret.

17] Sugiyono. (2012). Memahami Penelitian Kualitatif, Kuantitatif. Bandung: Alfabeta.

18] Sulasmi, \& Ibrahim. (2018). Faktor-faktor yang Mempengaruhi Penggunaan APD pada Penyapu Jalan di Sepanjang Jalan Veteran Kota Makassar. Jurnal Sulolipu: Media Komunikasi Sivitas Akademika dan Masyakarat, 18(1), 59-65. doi:https://doi.org/10.32382/sulolipu.v18i1 .728

19] Wapah, \& Wijaya, L. (2020). Literatur Review: Hubungan Pengetahuan Dengan Kepatuhan Perawat Dalam Penggunaan Alat Pelindung Diri Dasar. Babul Ilmi Jurnal Ilmiah Multi Science Kesehatan, 12(2), 126-139. Retrieved from http://jurnal.stikes-aisyiyah-

palembang.ac.id/index.php/Kep/article/vie w/499

20] Warmuni, N. M., \& Rusminingsih, N. K. (2020). Hubungan Tingkat Pengetahuan dengan Kepatuhan Pemakaian APD Petugas Cleaning Service di Rumah Sakit Umum Bangli Tahun 2019. Jurnal Kesehatan Lingkungan, 10(1), 24-31. Retrieved from https://ejournal.poltekkesdenpasar.ac.id/index.php/JKL/article/view/ 1087

21] WHO. (2012). Data and Statistics. Retrieved Maret 21, 2020, from http://www.who.int/gho/child_health/en/in dex.html 2012

22] Winarti, R. (2018). Hubungan Pengetahuan, Sikap, dan Motivasi Praktek Perawat dalam Penggunaan Alat Pelindung Dri di RSUD Soewondo Kendal. Jurnal Ilmu dan Teknologi Kesehatan, 9(2), 96111. doi:https://doi.org/10.33666/jitk.v9i2.193 